\title{
Characteristics of the hidden economy in Hungary before and after the regime change
}

\author{
Éva Fenyvesi, Tibor Pintér \\ Budapest Business School, Faculty of Commerce, Catering and Tourism
}

\begin{tabular}{|c|c|}
\hline A B S T RACT & ARTICLE INFO \\
\hline $\begin{array}{l}\text { Lately, economists and policymakers have been paying even closer } \\
\text { attention to the hidden economy. Indeed, it makes a difference to the } \\
\text { economy how much money goes into the state coffers. In order to uncover } \\
\text { the hidden economy however, it is necessary to be familiar with its nature } \\
\text { and manifestations. In this paper, with the aid of previous research and } \\
\text { literature we attempt to illustrate the characteristics of the hidden economy } \\
\text { in Hungary before and after the regime change and to map out the steps } \\
\text { that have been taken to uncover it. This publication was preceded by a } \\
\text { systematic literature review on the definition, causes, and effects of the } \\
\text { hidden economy, consisting of the collection of both data and literature } \\
\text { related to the domestic hidden economy. The following summarize the } \\
\text { results from the synthesis of literature: The Hungarian hidden economy } \\
\text { existed even before the regime change and took a variety of different } \\
\text { forms. These include tips, bribes, informal payments, unauthorized work } \\
\text { and patchwork, moonlighting, unauthorized rental of real estate, use of } \\
\text { social property for personal gain, gains from the infringement of customs } \\
\text { and exchange law, tax fraud by craftsmen and retailers, theft of public } \\
\text { property, and corruption. Since 1990, not only have the dynamics of the } \\
\text { hidden economy strengthened, but its types of activities have changed } \\
\text { significantly as well. These include, but are not limited to: omitting a } \\
\text { portion of revenue from the register; recognizing non-incurred material } \\
\text { production costs among expenditures; including an excessive portion of } \\
\text { personal household maintenance costs among production costs; organizing } \\
\text { business and study trips abroad; finder's fee; end-of-year depreciation or } \\
\text { 'transfer' of inventories; wages of registered employees paid out of pocket; } \\
\text { employment of unreported employees; parallel company formation; } \\
\text { economic activity of unincorporated individuals and the income generated } \\
\text { thereby. The following are among the concrete steps taken in recent years } \\
\text { to uncover the Hungarian hidden economy: the temporary employment } \\
\text { booklet; the simplified entrepreneurial tax; the Electronic Trade and } \\
\text { Transport Control System; online cash registers; the connection of vending } \\
\text { machines to the tax office. }\end{array}$ & $\begin{array}{l}\text { Article history: } \\
\text { Received } 07012020 \\
\text { Revised } 11022020 \\
\text { Accepted } 22032020 \\
\\
\text { This article was presented at } \\
\text { the 8th International OFEL } \\
\text { Conference on Governance, } \\
\text { Management and } \\
\text { Entrepreneurship. From } \\
\text { Corporations to Social } \\
\text { Entrepreneurs: } \\
\text { Exploring the Different } \\
\text { Faces of Social Innovation } \\
\text { (April 17th - 18th, 2020, } \\
\text { Dubrovnik, Croatia, } \\
\text { Governance Research and } \\
\text { Development Centre } \\
\text { CIRU), Zagreb, pp. 25-34 }\end{array}$ \\
\hline
\end{tabular}

\section{INTRODUCTION}

Hassan and Schneider (2016) studied 157 countries around the world and gave a very diverse picture regarding the development of the hidden economy. There are examples for each case, some of which we have highlighted here (Figure 1). We find countries where the hidden economy has significantly declined, some countries where it remains stagnant, and others where it has greatly increased between 1999 and 2013. There are countries where the hidden economy barely reaches 10\%, 
such as Switzerland, Austria and the United States. There are others where it surpasses $70 \%$, such as Bolivia, Honduras and Guatemala.

The author's twofold objective is to fill a very large gap in determining the "true" size of the hidden economy, since so far both static and dynamic comparisons have had multiple sources of error. For example, just consider the ever-changing definitions of hidden economy or the various measurement methods applied in different countries.

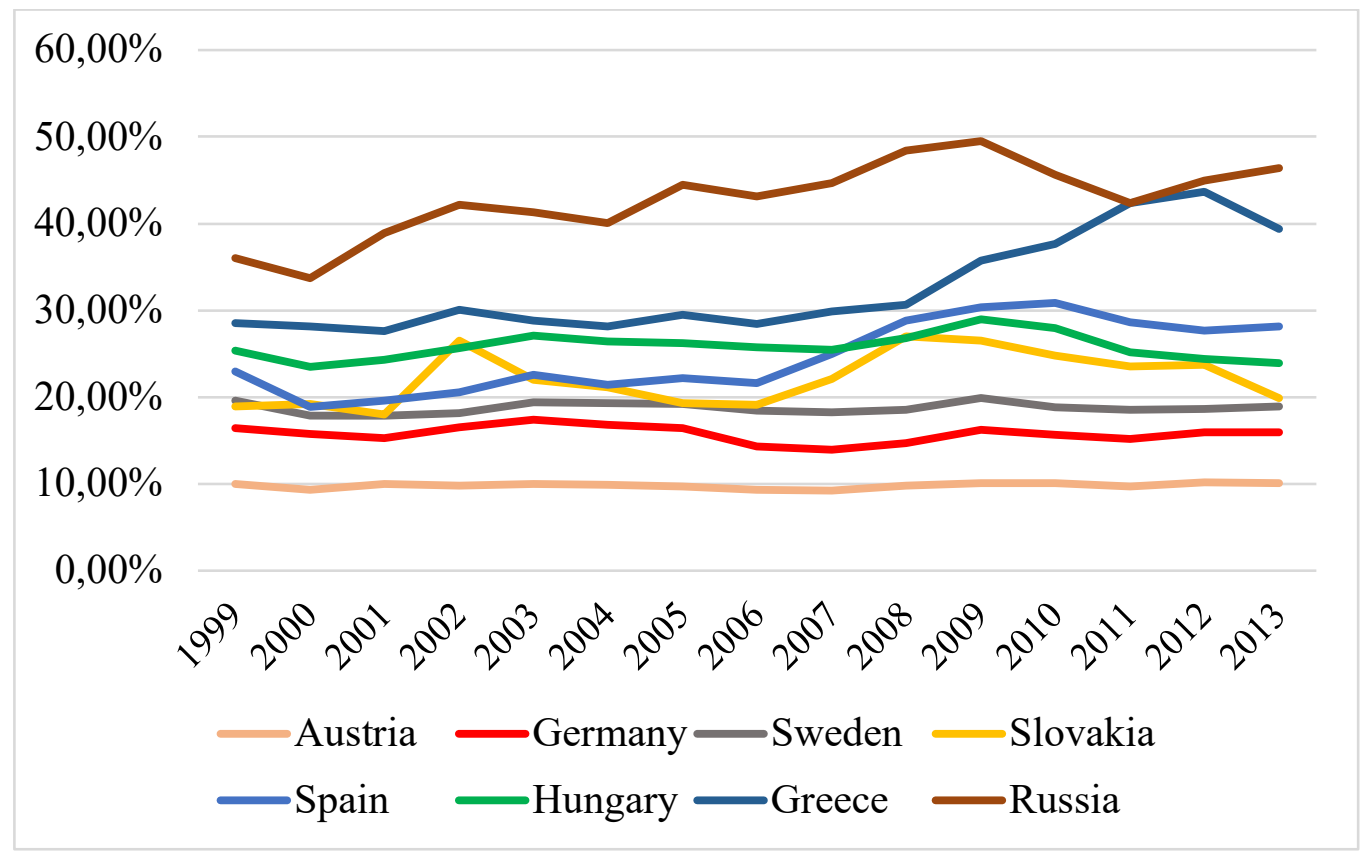

Figure 1. The size of the hidden economy as a percentage of the GDP (1999-2013) Source:

Edited by authors based on Hassan and Schneider (2016)

This topic first came up in the 20th century and has inspired many researchers to this day. Even during the initial phase, many people were interested in mapping out the hidden economy. For example, we can find observations of the underground economy in Helfferich's 1914 work. However, research on the subject increased significantly during the 1980s. First, the academic sphere began addressing this issue in the late 1970s. Feige (1979) blamed inaccurate statistical information for the fact that macroeconomics was unable to make adequate economic policy proposals. A decade later, measuring the hidden economy began to occupy the statistical offices of many countries. At this point, clarifying various concepts became a truly central objective.

\section{MATERIALS AND METHODS}

Literature reviews are needed in most of disciplines as volume of scientific publication has been increasing significantly. Due to the mass of publication, researchers could not have always opportunity to examine in detail the literature of a given topic.

PAGE 2| Journal of Corporate Governance, Insurance, and Risk Management | 2020, VOL. 7, Series. 2 
There are several advantages of processing literature: They could be useful for those who are researching the topics, as they can find the information, which are emphasized in different studies, in one place without spending a lot of time for quest of relevant literatures. They provide unbiased information about studies in a given discipline for the readers. Beyond that, they can help to determine the scope of further studies.

This publication was preceded by a systematic literature review on the definition, causes, and effects of the hidden economy, consisting of the collection of both data and literature related to the domestic hidden economy. While exploring the relevant literature verifiable scientific value and thus the restriction of place of publication of the selected works played a primary role. The following databases were utilized during our searches: Web of Science, MATARKA, Google Scholar and the ARCANUM database.

\section{DEFINITION OF HIDDEN ECONOMY}

There are many difficulties facing conceptual clarification. Among other things, publishers on the subject refer to the hidden economy using numerous expressions (unofficial, underground, unregistered, second, irregular, etc) (Table 1).

Table 1. Most of the terminology available in the literature

\begin{tabular}{|c|c|c|c|}
\hline Black & Cash-in-hand & Peripheral & Concealed \\
\hline Hidden & Everyday & Submerged & Marginal \\
\hline Second & Off-the-books & Irregular & Occult \\
\hline Grey & Non-observed & Unobserved & Clandestine \\
\hline Shadow & Subterranean & Parallel & Untaxed \\
\hline Dual & Non-official & Unrecorded & Precarious \\
\hline Ghetto & Unregulated & Underground & Twilight \\
\hline Moonlight & Unofficial & Unorganised & Invisible \\
\hline Other & Unexposed & Underwater & \\
\hline
\end{tabular}

Source: Edited by authors based on Williams (2004)

There are different names that cover more or less the same content, but there are also cases when multiple definitions are all headed by a single name. For example, there are authors who believe that hidden economy includes only informal activities (households and their production, unregistered companies) and underground activities (such as tax evasion, not respecting minimum wages, failing to meet health and safety standards). (Sík and Tóth, 1998; Dell'Anno, 2003; Belyó, 2008; Lackó et al., 2009) Others believe that in addition to these, the hidden economy also includes illegal activities, meaning the production, sale or possession of goods and services prohibited by law. (Schneider and 
Enste, 2004; Balogh, 2014; Csomós and Kreiszné, 2015; Bejaković, 2015) To give an example of different names referring to similar content, we would point out 'unobserved economy' as defined by Lackó et al. (2009) and 'irregular economy' of Feige (1979). These names further include barter transactions, activities performed under the guise of cooperative volunteer work, and services performed within households.

A uniform definition of hidden economy has other limitations as well. According to Belyó (2012, p. 28), "The difficulty of defining is due, among other things, to the dynamic nature of the licit economy and, as a result, to the dynamic nature of definitions related to the licit economy. The economy evolves over time, adapting to "de facto" changes in national economies (eg government regulation, general social attitudes and changes in the SNA)."

Due to the issues mentioned above, most of the concepts remain in the form of a general description. One of the early definitions comes from Feige (1979), according to which the hidden economy includes economic activities that are unreported or cannot be measured using current measurement techniques. Another broad definition is that the hidden economy consists of all unregistered economic activities that contribute to the officially calculated GDP. (Schneider and Enste, 2004)

There are authors who try to describe the hidden economy from various aspects. For example, Fekete and co-authors (Fekete et al., 2008) have approached the definition of hidden economy from several aspects (legal, ethical, statistical, political economy, or taxation).

From legal aspect the hidden economy means wrongdoer economical activities or pursue legal economical activities in illegal way.

From ethical (public perception) aspect the black can turn into grey, or moreover into white in some case based on the social justice, fairness or usefulness, contrarily, the activities of wanglers, who follow the words of law but act against public interest, can be ranged to black.

From statistical aspect it is hidden part of national economy production which can be only estimated with indirect methods in most cases.

Political economy evaluates it based on its hurtful effects to economy. Accordingly, all elements of statistically unobserved economy, such as food production of households for their own consumption, are not included, on the other hand certain economical activities - like avoiding tax and customs payment - which are not considered as production are included.

According to taxation approach, the hidden economy means economical activities with tax evasion. Such activities could be include into this which are not productions and so they do not make added value but tax should be paid after it. On the other hand, illegal activities, like illegal drug trafficking which are seemed production in statistics, are not included.

\section{THE HIDDEN ECONOMY IN HUNGARY}

PAGE 4| Journal of Corporate Governance, Insurance, and Risk Management | 2020, VOL. 7, Series. 2 
The hidden economy can only be examined in its dynamics, as its components are constantly changing. This is especially true of the former socialist countries, since their components changed significantly before and after the regime change.

According to Kereszty (1996), there are 3 main stages in the development of the hidden, as he denotes it, "black economy."

1. The first stage is the period of formation, which dates back to the 1970s. It was characterized as being of a local nature, varying by region and by industry, and not of a significant size. The participants were motivated by the need to obtain a private benefit from state-owned companies and cooperatives, which served to meet their personal needs.

2. From the 1980s to the regime change. The methods remained unchanged, but the liberalization of the economy made it possible to accumulate significant wealth, mainly cash and currency, to build flats, homes, and resorts, and to purchase high-value Western brand cars. This period is considered the beginning of the initial capital accumulation.

3. From the early 1990s, holders of various illicit funds sought to take maximum advantage of the opportunities offered by the transformation of the economic system. In addition, the adventure capital arriving from beyond our borders and the often irresponsible lending practices of domestic financial institutions put billions into private hands without collateral or remuneration.

In the following, we divide the description of the hidden economy's characteristics into just two groups: before and after the regime change.

\section{THE HIDDEN ECONOMY BEFORE THE REGIME CHANGE IN HUNGARY}

The second economy (the hidden economy) derives from the structural deficiencies of the socialist planned system and from the cultural and historical development of certain Eastern European countries. Ironically, the second economies of these countries correspond with the counterparts the primary economies of capitalist countries. (Sampson, 1987)

There was no personal income tax in the countries of Central and Eastern Europe before the regime change, and salaries were determined in such a way that they did not have to cover various taxes or social benefits. At that time, the basic needs of the majority of society could be met from fulltime earnings, and the main purpose of second-economy activities was "merely" to provide additional income. (Enyedi and Tamási, 1995)

Thus, socialist countries, where the hidden economy was intrinsically linked to the shortage economy, began to address this issue at a time when the problems of the state-owned economic system were becoming more prominent. (Lackó, 1995)

In the early 1980s, Hungary was the first country in the then European Socialist region to begin researching the hidden economy. The aim was primarily to estimate the size of the income generated PAGE 5| Journal of Corporate Governance, Insurance, and Risk Management | 2020, VOL. 7, Series. 2 
by the hidden economy, as there was a contradiction between statistically reported income and level of well-being experienced. (Ékes, 1995)

For the study of the 1980s, the Economic Research Institute drew a line between transactions which do and do not involve the transfer of a sum of money. This includes economic crimes (fraud, embezzlement, corruption) and business theft, estimates of which were also attempted. The types of income recognized as invisible income at that time were tips, bribes, gratuities related to health and legal services, unauthorized work and patchwork, unauthorized rental of real estate, use of social property for personal gain (i.e., unauthorized work making use of company equipment), gains from the infringement of customs and exchange law, tax fraud by craftsmen and retailers, gains from consumer harm, real estate speculation, theft of public property, corruption, fraud, and embezzlement. Research at the time left out activities that are commonly referred to as "moonlighting" today. As there was no extensive income tax, no tax was paid on these special forms of income. Their untaxed sums were not illegal and their extent, in turn, was unknown. In addition, underground trading and the interest on lending between households was left out of estimates. This was later estimated for the first time in the Consumer Price Index. (Ékes, 1995)

\section{THE HIDDEN ECONOMY AFTER THE REGIME CHANGE IN HUNGARY}

In post-socialist countries, where the shortage economy gradually became a market economy, analysing and quantifying the hidden economy became an important task on the one hand because of the growing budget deficit and on the other hand because official statistics revealed large-scale production declines that were difficult to accept without estimates of the hidden economy's size. (Lackó, 1995)

The growth of the hidden economy during this period is essentially attributable to the following. (Ékes, 1995)

1. Transitioning a country's economy from one type of regulatory system to another is a formidable task. To do so, a new legal environment must be established that conflicts with the policies, regulations, and laws of the past. As a result, the entire period of transition is fraught with conflicting legislation and filled with situations that are not legally covered, meaning the existence of many loopholes.

2. Another circumstance that contributed to the expansion of the hidden economy was the spread of the private sphere. One of the fundamental conditions for the growth of the hidden economy is the possibility to conceal income. The more direct the buyer-seller or employeremployee relationships are, the easier this is. The proliferation of small organizations helps this process. In an organization consisting of a few individuals, all forms of income concealment are much simpler than in a large one; where the owner is the manager and the chief accountant as well as the cashier, the necessary controls are not in place. 
3. Finally, there is a strange duality that prevails in the income distribution system, which also contributes to the spread of the hidden economy. With the exception of certain sectors banking, some businesses, etc - wages based on the consensus of socialism are still common in the economy to this day. Meanwhile, other forms of distribution are seeking to become market-economy conforming (taxation, elimination of consumer price supports, introduction of principles regarding Social Security benefits, etc). The end result is widespread poverty, which contributes to hidden economic activity.

Semjén and Tóth (Semjén and Tóth, 2004) explained the growing importance of the hidden economy in the first phase of the economic transition at a time of transformation crisis as follows: a major economic downturn, limited resources for tax auditing and the initially low effectiveness of the auditing, the underdevelopment of market institutions, and the breakdown of contractual relationships.

After the regime change, the most typical forms, methods, and techniques used by economic agents in order to maximize their entrepreneurial income and employee compensation while at the same time minimizing tax, social security, and other obligations incumbent on them include: omitting a portion of revenue from the register; recognizing non-incurred material production costs among expenditures; including an excessive portion of personal household maintenance costs among production costs; the use or purchase of vehicles; organizing business and study trips abroad; allowances charged to representation and advertising expenses; finder's fee; purchase discounts; extra benefits for foreign businesses; end-of-year depreciation or 'transfer' of inventories; wages of registered employees paid out of pocket; employment of unreported employees; barter transactions for products or services that are not of equal value; parallel company formation; economic activity of unincorporated individuals and the income generated thereby. (Belyó, 1995)

In the years following the transformational downturn of the economic transition however, economic recovery fundamentally changed the behaviour of economic agents (government, businesses, households). Former incentives to participate in the hidden economy weakened and became obsolete, and at the same time, the tax audits became more effective as well. Accordingly, the behaviour of entrepreneurs and households in relation to the hidden economy changed, the importance of the hidden economy began to decline, and breaches of contractual obligations and violations of tax and financial discipline reduced in the Hungarian corporate sector (Semjén and Tóth, 2004).

In the years following the crisis of 2008, the problem of the shadow economy became once again more acute, especially for countries in transition, which still to this day face many structural imbalances inherited from the period of the planned economy. After all, the shadow economy reduces the amount of budgetary resources available to implement anti-crisis measures. (Fedajev and Arsić, 2017)

Most sources estimate the size of the Hungarian hidden economy at $20-25 \%$. According to the study mentioned in the introduction, the hidden economy amounted to between $22 \%$ and $25 \%$ of Hungary's GDP between 2003 and 2013. (Schneider, 2016) It is not entirely comparable with the PAGE 7| Journal of Corporate Governance, Insurance, and Risk Management | 2020, VOL. 7, Series. 2 
above, but it is important from a statistical economics point of view that the HCSO also uses estimates in its GDP calculations for activities and incomes that are declared below their true value or not registered at all. According to the estimation of the HCSO, they amounted to 15.3 percent of GDP in 2002 and 14.9 percent of GDP in 2005. (Balogh, 2014)

Belyó's 2016 research also fits in with the data below (Table 2). According to this, in Hungary, the proportion of the hidden economy in relation to the GDP did not change between 2010 and 2016. However, this does not mean that the size of the hidden economy is stagnant. While official GDP continued to grow between 2010 and 2019, the size of the hidden economy declined in the first years of 2010 and then started to grow strongly from 2014 onwards. This also means that the hidden economy is a decisive component of GDP growth during this period.

1Table 2. The size of the official GDP and the hidden economy (2017 estimate)

\begin{tabular}{|c|c|c|c|c|}
\hline Year & $\begin{array}{c}\text { Official GDP } \\
\text { (millions HUF) }\end{array}$ & $\begin{array}{c}\text { Estimated value of } \\
\text { hidden economic } \\
\text { activities } \\
\text { (millions HUF) }\end{array}$ & $\begin{array}{c}\text { Growth of the } \\
\text { hidden economy } \\
\mathbf{( 2 0 1 0 = 1 0 0 \% )}\end{array}$ & $\begin{array}{c}\text { Proportion of the } \\
\text { hidden economy in } \\
\text { relation to the } \\
\text { official GDP (\%) }\end{array}$ \\
\hline 2010 & 27051695 & 4057754 & & 15 \\
\hline 2011 & 28133826 & 3938736 & -2.93 & 14 \\
\hline 2012 & 28627889 & 4007904 & -1.23 & 13 \\
\hline 2013 & 30065005 & 3908451 & -3.68 & 13 \\
\hline 2014 & 32179666 & 4183357 & 3.10 & 13 \\
\hline 2015 & 33712000 & 4382560 & 8.00 & 13 \\
\hline 2016 & 35194000 & 4575220 & 12.75 & 19.50 \\
\hline 2017 & 37299000 & 4848870 & & 13 \\
\hline
\end{tabular}

Source: Edited by authors based on Belyó, 2016

\section{ACTIONS TAKEN TO UNCOVER THE HIDDEN ECONOMY IN HUNGARY}

The legalization of the hidden economy requires the implementation of complex instruments of economic policy. However, a successful package of measures cannot be conceived without a clear political will since for each measure infringing upon the interests of a particular group, the lobbyists of said group are able to repeatedly prevent the technically justified actions. It is important that only enforceable rules are introduced. Restrictive measures alone cannot succeed unless at the same time measures that shape the economic environment are taken and are clearly welcomed by honest businesses. (Belyó, 1995)

The changes proposed by Belyó (1995) prior to the turn of the millennium have been implemented almost one after another ever since: the system of the average tax institution; regulation 
of entrepreneurial cash flow; legalization of the declaration of assets; auditing of certain international financial operations; introduction of a company register; modification of the tax burden; adjusting the amount of the Social Security contribution; limiting the scope for black market trade.

According to the research of Eco-Vista (2016), several measures and initiatives have taken place in Hungary to promote the legal economy. This includes, for example, the establishment of the Hungarian Unified Labour Database (EMMA) after the country's accession to the EU. Labor inspections, which have already had quantifiable results, especially in the construction industry, have significantly increased. As of January 2008, illegal use of Social Security services is being sifted out. The Hungarian tax authority (today known as NAV in Hungarian) launched a campaign against VAT fraud, which is widespread in a variety of forms. A similar campaign had previously been launched against so-called bogus contracts as well. The modernization of administrative regulations has also begun, e.g. only legitimate companies can participate in public tenders.

Government actions combating the hidden economy can be divided into three groups. (Eco-Vista, 2016)

The first group measures that indirectly influence economic agents' decisions in relation to the hidden economy. These are steps to improve the security of business relationships. They include: predictable taxation, striving for tax rule transparency; establishing and operating efficient, verifiable, inexpensive, and easily accessible company information systems.

Second group of measures includes those taken directly to suppress the hidden economy. These include increasing the frequency of tax audits and the budget of audit apparatuses. Further, this includes increasing the effectiveness of audits but also rendering penalties more severe and determining optimal tax rates.

The third group may be formed from the measures that strengthen tax compliance and increase the moral costs related to tax evasion. Auditing, or the possibility thereof, and penalties are strong deterrents helping to reduce participation in the hidden economy. This is the reason why it is worth creating and maintaining a tax collection and auditing system with a modern infrastructure that is predictable and transparent. However, the maintenance of the control apparatus, the imposition of sanctions and their related penalties related to sanctions entails significant costs for taxpayers. These costs cannot be increased arbitrarily: after reaching a certain level within the hidden economy, it is no longer worth pumping more money into the auditing and sanctioning apparatus because the marginal yield of increasing activity will be negative.

\section{THE ACTIONS INTRODUCED IN HUNGARY IN RECENT YEARS AND THEIR EFFECT ON UNCOVERING THE HIDDEN ECONOMY}

- The temporary employment booklet (AM booklet)

A 2008 study looked at the impact of introducing the temporary employment booklet to uncover and suppress certain forms of unreported employment and the impact of introducing the simplified PAGE 9| Journal of Corporate Governance, Insurance, and Risk Management | 2020, VOL. 7, Series. 2 
entrepreneurial tax (EVA) to improve the tax discipline of small businesses. According to the results of the research, the vast majority of AM booklet users (79\%) committed fraud to some extent in their use of the booklet. The most typical way to do this is not to register part of one's working day and affix a smaller denomination stamp (generally the smallest, 400 HUF). Hidden employment through such fraudulence was most characteristic of the construction industry, with a slightly better result in the hospitality and trade sectors. However, it was generally found that in all sectors the AM booklet was working towards promoting the legal economy; typically, entirely illegal employment became semi-legal. (Fazekas and Semjén, 2008)

- $\quad$ The simplified entrepreneurial tax (EVA)

With the introduction of the simplified entrepreneurial tax (EVA) on January 1, 2003, the government was aiming to reduce the administrative and tax burden on micro and small businesses, thereby increasing their economic activity and reducing their competitive disadvantage compared to larger enterprises. On the fiscal side, the aim was to improve tax compliance, increase revenues and make tax policy more transparent. According to one study, the clear effect of EVA is that it has reduced the amount of tax evasion among those who converted to it and the so-called "exaggerated expense deduction" and "invoice production / purchase" have been practically eliminated among entrepreneurs who have switched to EVA. (Fazekas and Semjén, 2008)

\section{- Online cash registers}

The introduction of online cash registers also served to promote the legal economy. Research in this area found that the retail sector saw a 20-25 percent increase in revenue for the smallest companies as a result of connecting to online cash registers and a 4-6 percent increase for mediumsized companies. Within this, the largest growth was in the consolidated accommodation and hospitality sector, with reported sales having increased by about 32-37 percent. (Lovics, et al., 2019)

\section{- Electronic Trade and Transport Control System (EKÁER)}

EKÁER is a technical system for monitoring, controlling and registering the movement of goods, created and operated by the Hungarian National Tax and Customs Board. Its primary objective is to reduce the amount of abuses related to the transport of goods as well as VAT fraud. The system covers transactions between Member States as well as movements of goods for sale to the first domestic, nonfinal user. It also includes prior electronic filing with tax authorities of these statutory data and the reporting of delivery. This can indirectly lead to the elimination of the hidden economy, since by knowing the actual movement of the goods, the legal fate of the products supplied can also be verified by the combined use of NAV and HU-GO (a traffic monitoring camera system installed on the Hungarian road system, which tracks the movement of road toll vehicles and compiles a database of the information obtained since 2013). These two digital systems make it possible to significantly reduce the volume of goods traded without being taxed, as the only goods that can legally reach the market by road transport are those which have been duly reported in advance. This instrument indirectly protects honest market players and customers acting in good faith, improves equality of PAGE 10| Journal of Corporate Governance, Insurance, and Risk Management | 2020, VOL. 7, Series. 2 
public burden sharing, and helps to substantiate government statistics and ensure sound economic policy planning. (Szilovics, 2019)

- The connection of vending machines to the tax office

By the end of August 2019, all vending machines had to be connected to the tax office. The Ministry of Finance estimates that the current registration requirement may have a positive impact on tax compliance. In fact, NAV risk analysts can even compare this year's entrepreneurial income data with the traffic data that will arrive online at the tax office, and in the event of a large discrepancy, risk analysts pass the data collected to the auditors for further investigation.

\section{CONCLUSIONS}

Examining the hidden economy is a complex task from several aspects. The precise definition of the concept of the hidden economy also created a general specialized literature. The characteristics of the hidden economy in Hungary are worth examining before and after the change of regime. The scale of the tax system was not particularly prominent in the earlier period. Later, in the second section several factors influenced the processes. Privatization, liberalization, trans nationalization and the EUaccession also affected the state of the hidden economy. Today, uncovering (whitening) the economy is the dominant trend of the economic policy. The general attitude of society towards economic issues and economic development is also decisive factor to deal with in the future. At this point, the problem is also linked to the field of new institutional economics.

\section{REFERENCES}

Balog, Á. 2014. Adóelkerülés és rejtett gazdaság Magyarországon. Köz-gazdaság: tudományos füzetek, 9(4), pp. 15-30.

Bejaković, P. 2015. A revision of the shadow economy in Croatia: causes and effects. Economic Research, 28(1), pp. 422-440 DOI: 10.1080/1331677X.2015.1059104

Belyó, P. 1995. A rejtett gazdaság fogalma és súlya. INFO-Társadalomtudomány 1995(33) pp.13-22.

Belyó, P. 2008. A rejtett gazdaság nagysága és jellemzői. Statisztikai Szemle, 86(2), pp. 113-137.

Belyó, P. 2012. A rejtett gazdaság előretörése az új gazdaságpolitikai gyakorlat következtében. In: Márkus, Gy. (ed.) XXI. század - Tudományos Közlemények, 2012(27), pp. 25-46. Budapest: Általános Vállalkozási Főiskola.

Belyó, P. 2016. A „rejtett gazdaság” alakulása (kutatás a vállalkozások és a lakosság körében). In: Jandala, Cs. (ed.) Acta Periodica 11. kötet. (pp. 15-29) Tatabánya: EDUTUS Föiskola.

Csomós, B. and Kreiszné Hudák, E. 2015. A rejtett gazdaság mértékének csökkentése Magyarországon. MNB, Kiadványok, szakmai cikkek. Retrieved December, 10, 2019, from https://www.mnb.hu/kiadvanyok/szakmai-cikkek/tovabbi-szakmai-cikkek/csomos-balazs-kreisznehudak-emese-a-rejtett-gazdasag-mertekenek-csokkentese-magyarorszagon

PAGE 11| Journal of Corporate Governance, Insurance, and Risk Management | 2020, VOL. 7, Series. 2 
Dell'Anno, R. 2003. Estimating the Shadow Economy. In Italy: A Structural Equation Approach, Working Paper 2003-7, Aarhus, Denmark: Department of Economics, University of Aarhus, pp. 1-37.

Eco-Vista Kft. 2016. Növekedési képességünk és a rejtett gazdaság. Retrieved August, 10, 2019, from https://www.parlament.hu/documents/126660/769617/N\%c3\%b6veked\%c3\%a9si+k\%c3\%a9pess\%c3 \%a9g\%c3\%bcnk+\%c3\%a9s+a+rejtett+gazdas\%c3\%alg+(2016).pdf/963758a6-0509-4c7e-bb90$\underline{7 \mathrm{fa} 6 \mathrm{a} 670 \mathrm{e} 9 \mathrm{c} 7}$

Ékes, I. 1995. A rejtett gazdaság és változása. Info-Társadalomtudomány. 1995(33) pp. 7-12.

Enyedi, Gy. and Tamási, P. 1995. A feketegazdaság: a piacgazdaság kísérőjelensége. InfoTársadalomtudomány 1995(33) pp. 3-6.

Fazekas, K. and Semjén, A. 2008. A rejtett gazdaságban való részvétel és csökkentésének kormányzati eszközei. MTA-MeH. Stratégiai kutatások 2007-2208, Kutatási jelentések, Budapest, pp. 213-233.

Fedajev, A. and Arsić, M. 2017. Drivers of shadow economy in transition countries during the postcrisis period: The results of structural model," Proceedings of FIKUSZ 2017. In: Fodor, M. (ed.), Proceedings of FIKUSZ '17, (pp. 20-34) Budapest: Óbuda University, Keleti Faculty of Business and Management.

Fekete, I., Ligeti, Cs. and Pataky, P. 2008. A gazdaság kifehéredését vizsgáló bizottság jelentése. Retrieved August, 16, 2019, from http://www.mkt.hu/docs/2008-02-18-11-58-01a\%20feheredesrol_2008-02.pdf

Feige, E. L. 1979. How Big is the Irregular Economy? Challenge 22(5), pp. 5-13.

(Hassan Schneider 2016) Hassan, M. and Schneider, F. 2016. Size and Development of the Shadow Economies of 157 Countries Worldwide: Updated and New Measures from 1999 to 2013. Discussion Paper No. 10281. IZA, Bonn

Helfferich, K. 1914. Deutschlands Volkswohlstand (Verlag von Georg Stilke, Berlin) In: Brugt, Kazemier (2006): Monitoring the Underground Economy. A Survey of methods and estimates. Statistics Netherlands, JM Voorburg, pp. 1888-1913

Kereszty, B. 1996. Gazdasági bünözés, feketegazdaság és a pénzmosás. Acta Universitatis Szegediensis: acta juridica et politica, 1996(48) pp. 137-150.

Lackó M., Semjén A., Fazekas M. and Tóth I. J. 2009. Rejtett gazdaság, rejtett foglalkoztatottság kutatási eredmények és kormányzati politika a nemzetközi és hazai irodalom tükrében. In: Semjén A. and Tóth I. J. (szerk.): Rejtett gazdaság: Be nem jelentett foglalkoztatás és jövedelemeltitkolás kormányzati lépések és a gazdasági szereplők válaszai. Budapest: MTA Közgazdaságtudományi Intézet

Lackó, M. 1995. Rejtett gazdaság nemzetközi összehasonlításban. Közgazdasági Szemle, 42(5). pp. 486-510.

Lovics, G., Szőke, K., Tóth G. Cs. and Ván, B. 2019. Megugrott a kis cégek bejelentett forgalma az online pénztárgépektöl. Retrieved December, 15, 2019, from https://www.portfolio.hu/gazdasag/20190531/kiszamoltak-igy-feheredik-a-magyar-gazdasag-325919

Nagy, I. Z. 1995. A feketegazdaság adópszichológiai szempontjai. Info-Társadalomtudomány 1995(33) pp. 41-49.

PAGE 12| Journal of Corporate Governance, Insurance, and Risk Management | 2020, VOL. 7, Series. 2 
Sampson, S. L. 1987. The Second Economy of the Soviet Union and Eastern Europe.

The ANNALS of the American Academy of Political and Social Science 493(1), pp. 120-136.

https://doi.org/10.1177/0002716287493001009

Schneider, F., - Enste H. D. 2004. The shadow economy: An international survey. Cambridge University Press, pp. 56-89.

Semjén, A. - Tóth, I. J. 2004. Rejtett gazdaság és adózási magatartás, magyar közepes és nagy cégek adózási magatartásának változása 1996-2001. Elemzések a rejtett gazdaság magyarországi szerepéröl. 4. tanulmány, Budapest: MTA KTI

Sík, E. - Tóth, I. J. 1998. A rejtett gazdaság néhány eleme a mai Magyarországon. In: Kolosi, T., Tóth, I., Gy. and Vukovich, Gy. (szerk.) Társadalmi riport. Budapest: TÁRKI, pp. 92-116

Szilovics, Cs. 2019. Az adócsalás elleni küzdelem új eszközéröl. Retrieved November, 20, 2019, from https://ujbtk.hu/prof-dr-szilovics-csaba-az-adocsalas-elleni-kuzdelem-uj-eszkozerol/

Williams, C. C. 2004. Cash-in-hand Work The Underground Sector and The Hidden Economy of Favours. Basingstoke: Palgrave Macmillan. 